\title{
Detection of Lyme disease and anaplasmosis pathogens via PCR in Pennsylvania deer ked
}

\author{
M. Buss, L. Case, B. Kearney, C. Coleman, and J.D. Henning \\ Department of Biology, University of Pittsburgh at Johnstown, Johnstown, PA 15904 U.S.A., henning@pitt.edu
}

Received 2 June 2016; Accepted 15 September 2016

\begin{abstract}
Borrelia burgdorferi and Anaplasma phagocytophilum are obligate intracellular parasites that maintain their life cycles in enzoonotic vector-host cycles with Ixodes scapularis as a vector. In addition to ticks, the hosts are commonly infested with insects from the Hippoboscidae family. This study confirms the presence of B. burgdorferi and A. phagocytophilum in deer keds (Lipoptena cervi) removed from white-tailed deer using PCR. Detection of these pathogens in deer ked represents a potential novel susceptibility of wildlife and also suggests the risk of transmission of these pathogens to humans and animals alike through the bite of an infected ectoparasite. This study represents the first instance in the U.S. of detection of tick-borne pathogens in a member of the Hippoboscid family. Journal of Vector Ecology 41 (2): 292-294. 2016.
\end{abstract}

Keyword Index: Borrelia burgdorferi, Anaplasma phagocytophilum, Lipoptena cervi, PCR.

\section{INTRODUCTION}

Borrelia burgdorferi, the causative agent of Lyme disease, is a motile gram-negative spirochete. Lyme disease is a progressive and potentially debilitating disease that is the most commonly reported vector-borne illness in the U.S. Infection rates with Borrelia burgdorferi have increased in the northeast and upper Midwest in the past 40 years (Steere et al. 2004). In 2014, these geographical regions reported $96 \%$ of all Lyme disease cases. The number of confirmed cases in Pennsylvania during 2014 was 6,470, with an incidence rate of 50.6/100,000 people. Massachusetts had the second largest number with 3,646 confirmed cases and an incidence rate of 54.1 per 100,000 people (Centers for Disease Control and Prevention. 2013. Lyme Disease Data).

Anaplasma phagocytophilum is a gram-negative, obligate intracellular bacterium that causes anaplasmosis. This bacterium obtains nutrients in an early endosome and then grows into a morula within the leukocytes, platelets, and erythrocytes (Dumler et al. 2005). During 2010 in the U.S., there were an estimated 1,750 cases of anaplasmosis, a $52 \%$ increase from the prior year. However, in that same year, there were no reported cases of human granulocytic anaplasmosis in Pennsylvania, which could be due to the high rate of Lyme disease and the similarity between the two diseases producing differential diagnostic errors.

Lipoptena cervi, also known as the deer ked, is a hematophagous ectoparasite native to Europe that was introduced into North America in the 1800s. It is found in New Hampshire, Massachusetts, Pennsylvania, and New York (Samuel et al. 2012, Bequaert 1937, 1942, 1953, 1957). L. cervi typically infests Odocoileus virginianus, or white tailed deer, by crawling into the coat of its host. $L$. cervi then proceeds to shed its wings and take a blood meal. After becoming engorged, it deposits pre-pupae that are wingless and fall from the hair of the host but remain in close circumference to the hatching site (Madslien et al. 2012). The pre-pupae remain flightless from early summer through July. The development of wings signifies the start of the adult stage in the life cycle of $L$. cervi. From late July into fall, the newly developed adults are able to infest other animals. Once a host is selected, the deer ked lives approximately 120 to 180 days (Paakkonen et al. 2010).

Humans serve as accidental hosts for L. cervi (Madslien et al. 2012). Deer ked often encounter humans and will temporarily parasitize them due to the presence of hair on the human body (Paakkonen et al. 2010). This occurs with frequency due to the swarming habits of $L$. cervi (Duodu et al. 2013). In a study conducted by Víchová et al. (2011),113 deer ked were tested for A. phagocytophilum using nested PCR with two being positive. This study suggested that the deer ked is a possible mechanical vector for the transmission of $A$. phagocytophilum to other hosts.

The goal of our study was to investigate whether $B$. burgdorferi and $A$. phagocytophilum, the agents of Lyme disease and anaplasmosis of humans and animals, respectively, occurs in deer keds collected from $O$. virginianus, which are a naturally infected reservoir host of these bacteria, in Pennsylvania.

\section{MATERIALS AND METHODS}

\section{Collection of deer ked}

Forty-eight Lipoptena cervi were collected in the summer of 2015 from Blair and Indiana counties on Pennsylvania State Game Lands 184 (40.33N, 78.28W) (nine keds) and 276 $(40.65 \mathrm{~N}, 79.09 \mathrm{~W})(39 \mathrm{keds})$, and were stored in $100 \%$ ethanol until DNA extraction was performed. The deer keds were removed from freshly harvested O. virginianus. All L. cervi collected were wingless adults. Samples were then prepared for DNA extraction by freezing for a minimum time of 15 min.

DNA extraction from $L$. cervi was conducted using the Qiagen DNeasy protocol according to the manufacturer's 
Table 1. Spatial distributions of B. burgdorferi and A. phagocytophilium in L. cervi collected in southwestern Pennsylvania.

\begin{tabular}{ccccc}
\hline Collection site & $\mathrm{n}$ & $\begin{array}{c}\text { No. (\%) PCR positive } \\
\text { for B. burgdorferi }\end{array}$ & $\begin{array}{c}\text { No. (\%) PCR positive } \\
\text { for A. phagocytophilum }\end{array}$ & $\begin{array}{c}\text { No. (\%) of co- } \\
\text { infected samples }\end{array}$ \\
\hline Blair & 9 & $7(77.7 \%)$ & $1(11.1 \%)$ & $1(11.1 \%)$ \\
Indiana & 39 & $12(30.8 \%)$ & $13(33.3 \%)$ & $2(5.13 \%)$ \\
TOTAL & 48 & $19(39.58 \%)$ & $14(29.12 \%)$ & $3(6.25 \%)$ \\
\hline
\end{tabular}

purification of total DNA from animal tissues protocol. The DNA was stored at $-20^{\circ} \mathrm{C}$ until PCR analysis so quantification could be performed (Brown et al. 2015).

\section{DNA analysis}

The DNA was amplified by PCR. Briefly, the initial denaturing was at $95^{\circ} \mathrm{C}$ for a period of $2 \mathrm{~min}, 40$ cycles of $30 \mathrm{~s}$ at $94^{\circ} \mathrm{C}, 30 \mathrm{~s}$ at $55^{\circ} \mathrm{C}$, and $1 \mathrm{~min}$ at $72^{\circ} \mathrm{C}$. On positive samples, a nested PCR assay targeting a 546-bp amplicon of the $16 \mathrm{~S}$ rRNA gene was utilized for A. phagocytophilum (Brown et al. 2015). To identify specimens infected with B. burgdorferi, nested PCR amplifying a 390-bp amplicon from the fla gene was performed. PCRs for both organisms were done with Promega GoTaq Master Mix. An Eppendorf thermocycler was used for analysis of the $50 \mu \mathrm{l}$ reactions.

\section{RESULTS}

Forty-eight Lipoptena cervi were collected from southwestern Pennsylvania. There were 19 (39.58\%) deer keds positive for Borrelia burgdorferi and 14 (29.12\%) deer keds positive for Anaplasma phagocytophlyum. Out of the 48 deer ked, three $(6.25 \%)$ were co-infected with the etiologic agents of Lyme disease and anaplasmosis (Table 1).

\section{DISCUSSION}

Borrelia burgdorferi and Anaplasma phagocytophlyum are tick-borne obligate intracellular parasites whose normal reservoirs are small mammals and deer. These pathogens circulate in the enzootic cycle, with Ixodes scapularis being the principal vector of these organisms in the northeastern and upper midwestern United States (Walker et al. 1996). Although Ixodes scapularis is primarily known for its role in transmitting these organisms, other blood-sucking arthropods infest the same hosts as I. scapularis and could acquire the pathogen upon taking a blood meal. One such ectoparasite of cervids, Lipoptena cervi, has been shown to harbor the DNA from these pathogens in Europe (Víchová et al. 2011, de Bruin et al. 2015). Also, L. cervi is able to transmit A. phagocytophilum from the reservoir hosts to susceptible sterile hosts via their bite (De La Fuente et al. 2005).

Humans are accidental hosts for I. scapularis and L. cervi (Berger 1989, Madslien et al. 2012). Deer ked often encounter humans and will temporarily parasitize them due to the presence of hair on the human body (Paakkonen et al. 2010). Hunters may be exposed to ectoparasites while harvesting white-tailed deer, increasing the risk of exposure to both $I$. scpaularis and L. cervi.

In our study, deer keds were examined for the presence of B. burgdorferi and A. phagocytophilum using PCR. We found that both pathogens were present in the deer keds. Of the 48 deer keds examined, 19 were positive for B. burgdorferi DNA, seven from Blair county and 12 from Indian county, and 14 were positive for A. phagocytophilum, one from Blair county and 13 from Indiana county (co-infection of three ked). Using a Fisher's exact test, we found that the prevalence of $B$. burgdorferi is a statistically significant $\mathrm{p}=0.0195$ between counties. However, the prevalence of A. phagocytophilum is non-significant $(\mathrm{p}=0.25)$. The overall prevalence of infection reached $62.5 \%$ for at least one pathogen across counties (30/48).

A study of the prevalence of these pathogens in $I$. scapularis from our laboratory showed similar prevalence rates of $B$. burgdorferi and A. phagocytophilum in these counties (Brown et al. 2015). Recently, the Pennsylvania Department of Environmental Protection studying all 67 counties, stated that prevalence rates of B. burgdorferi in I. scapularis within the eastern and central regions of Pennsylvania are higher than those in the southern and western regions (Hutchinson et al. 2015). The increased prevalence of B. burdgorferi in the central portions of PA within the deer tick helps to support the increased prevalence our study shows in Blair county, as Blair county is part of the central region of PA.

Lipoptena cervi typically seek reindeer, deer, moose, horses, and cattle as their hosts, but the concern is that they may begin to target other mammals (Kaunisto et al. 2009). Transmission of B. burgdorferi and A. phagocytophilum could migrate to other mammals and eventually reach humans. There is no evidence thus far that suggests that deer ked bite or transmit B. burgdorferi or A. phagocytophilum to humans. However, humans are accidental hosts for L. cervi and could be exposed to these pathogens via exposure to the keds, as it takes 15-20 mins for an adult deer ked to take a blood meal on a human (Haarløv 1964, Hackman et al. 1983, Rantanen et al. 1982). This is not to say that deer keds cannot spread the pathogens to a larger area or other mammalian hosts. Transmission of pathogens between wildlife, humans, and domestic animals is common when there is mutual contact between the groups.

While we do not have the infection data on the whitetailed deer from which these ked were harvested, we presume that the deer ked acquired the infection from a blood meal on an infected deer. As suggested by Vichova et al. (2011) in the study from Europe, deer ked may be mechanical vectors for the transmission of B. burgdorferi and A. phagocytophilum. 
This study provides the first incidence of $B$. burgdorferi and $A$. phagocytophilum in deer ked harvested from wild cervids in the United States. This also suggests that the risk for transmission of these pathogens via the bite of $L$. cervi is present. Further research could explore the competency of the vector and whether it is biologic or mechanical.

\section{Acknowledgments}

The authors thank the President's Mentorship Fund and the Alice Waters Thomas Fund at the University of Pittsburgh at Johnstown for supporting this study. The following reagents were obtained through BEI Resources, NIAID, NIH: Ixodes scapularis, NR-42510 and NIAID, NIH: Borrelia burgdorferi, Strain B31 (Clone 5A1), NR-13251.

\section{REFERENCES CITED}

Bequaert, J. 1937. Notes on Hippoboscidae. 5. The American species of Lipoptena. Bulletin of the Brooklyn Entomological Society 32 (new series): 91-101.

Bequaert, J. 1942. A monograph of the Melophaginae, or ked-flies, of sheep, goats, deer and antelopes (Diptera, Hippoboscidae). Entomol. Amer. 22 (new series): 1-220.

Bequaert, J. 1953. The Hippoboscidae or louse-flies (Diptera) of mammals and birds. Part I. Structure, physiology and natural history. Entomol. Amer. 36 (new series): 211-442.

Bequaert, J. 1957. The Hippoboscidae or louseflies (Diptera) of mammals and birds. Part II. Taxonomy, evolution and revision of American genera and species. Entomol. Amer. 36 (new series): 417-611.

Berger, B.W. 1989. Dermatologic manifestations of Lyme disease. Rev Infect Dis 11 Suppl 6: S1475-1481.

Brown, S.M., P.M. Lehman, R.A. Kern, and J.D. Henning. 2015. Detection of Borrelia burgdorferi and Anaplasma phagocytophilum in the black-legged tick, Ixodes scapularis, within southwestern Pennsylvania. J. Vector Ecol. 40: 180-183.

de Bruin, A., A.D. van Leeuwen, S. Jahfari, W. Takken, M. Foldvari, L. Dremmel, H. Sprong, and G. Foldvari. 2015. Vertical transmission of Bartonella schoenbuchensis in Lipoptena cervi. Parasit. Vectors 8: 176.

De La Fuente, J., V. Naranjo, F. Ruiz-Fons, U. Hofle, I.G. Fernandez De Mera, D. Villanua, C. Almazan, A. Torina, S. Caracappa, K. M. Kocan, and C. Gortázar. 2005. Potential vertebrate reservoir hosts and invertebrate vectors of Anaplasma marginale and A. phagocytophilum in central Spain. Vector Borne Zoonot. Dis. 5: 390-401.

Dumler, J.S., K.S. Choi, J.C. Garcia-Garcia, N.S. Barat, D.G. Scorpio, J.W. Garyu, D.J. Grab, and J.S. Bakken. 2005. Human granulocytic anaplasmosis and Anaplasma phagocytophilum. Emerg. Infect. Dis. 11: 1828-1834.
Duodu, S., K. Madslien, E. Hjelm, Y. Molin, A. PaziewskaHarris, P.D. Harris, D.J. Colquhoun, and B. Ytrehus. 2013. Bartonella infections in deer keds (Lipoptena cervi) and moose (Alces alces) in Norway. Appl. Environ. Microbiol. 79: 322-327.

Haarløv N. 1964. Life cycle and distribution pattern of Lipoptena cervi (L.) (Dipt., Hippobosc.) on Danish deer. Oikos 15: 93-129

Hackman W,T. Rantanen, and P.Vuojolahti. 1983. Immigration of Lipoptena cervi (Diptera, Hippoboscidae) in Finland, with notes on its biology and medical significance. Not. Entomol. 63: 53-59.

Hutchinson, M. L., M. D. Strohecker, T. W. Simmons, A. D. Kyle, M. W. Helwig. 2015. Prevalence rates of Borrelia burgdorferi (Spirochaetales: Spirochaetaceae), Anaplasma phagocytophilum (Rickettsiales: Anaplasmataceae), and Babesia microti (Piroplasmida: Babesiidae) in hostseeking Ixodes scapularis (Acari: Ixodidae) from Pennsylvania. J. Med. Entomol. 52: 693-698.

Kaunisto, S., R. Kortet, L. Harkonen, S. Harkonen, H. Ylonen, and S. Laaksonen. 2009. New bedding site examinationbased method to analyse deer ked (Lipoptena cervi) infection in cervids. Parasitol. Res. 104: 919-925.

Madslien, K., B. Ytrehus, H. Viljugrein, E.J. Solberg, K.R. Braten, and A. Mysterud. 2012. Factors affecting deer ked (Lipoptena cervi) prevalence and infestation intensity in moose (Alces alces) in Norway. Parasit. Vectors 5: 251.

Paakkonen, T., A.M. Mustonen, H. Roininen, P. Niemela, V. Ruusila, and P. Nieminen. 2010. Parasitism of the deer ked, Lipoptena cervi, on the moose, Alces alces, in eastern Finland. Med. Vet. Entomol. 24: 411-417.

Rantanen, T., T. Reunala, P. Vuojolahti, and W. Hackman. 1982. Persistent pruritic papules from deer ked bites. Acta Dermatol. Venereol. 62: 307-311.

Samuel, W.M, K. Madslein, and J. Gonynor-McGuire. 2012. Review of Deer Ked (Lipoptena cervi) on moose in Scandinavia with implications for North America. ALCES 48: 27-33.

Steere, A.C., J. Coburn, and L. Glickstein. 2004. The emergence of Lyme disease. J. Clin. Invest. 113: 1093-1101.

Víchová, B., V. Majláthová, M. Nováková, I. Majláth, J. Čurlík, M. Bona, M. Komjáti-Nagyová, and B. Petko. 2011. PCR detection of re-emerging tick-borne pathogen, Anaplasma phagocytophilum, in deer ked (Lipoptena cervi) a blood-sucking ectoparasite of cervids. Biologia 66: 1082-1086.

Walker, D.H., A.G. Barbour, J.H. Oliver, R.S. Lane, J.S. Dumler, D.T. Dennis, D.H. Persing, A.F. Azad, and E. McSweegan. 1996. Emerging bacterial zoonotic and vector-borne diseases. Ecological and epidemiological factors. J. Am. Med. Assoc. 275: 463-469. 